\title{
Evaluation of nutritional, phytochemical, antioxidant and cytotoxic potential of Capsella bursa-pastoris, a wild vegetable from potohar region of Pakistan
}

\author{
Iqra Riaz ${ }^{1, *}$, Yamin Bibi ${ }^{*}$, Nabeela Ahmad ${ }^{1}$, Sobia $\mathrm{Nisa}^{2}$, Abdul Qayyum ${ }^{3}$ \\ ${ }^{I}$ Dept. of Botany, PMAS-Arid Agriculture University Rawalpindi, 46300 Pakistan \\ ${ }^{2}$ Dept. of Microbiology, The University of Haripur, 22620 Pakistan \\ ${ }^{2}$ Dept. of Agronomy, The University of Haripur, 22620 Pakistan \\ *Corresponding authors: iqrariaz677@gmail.com
}

\begin{abstract}
Capsella bursa-pastoris has been analyzed for nutritional composition, antioxidant and cytotoxic potential to reveal its nutraceutical and medicinal importance. Methanol and chloroform extracts were used for preliminary phytochemical analysis following quantification of total phenolic, flavonoid, tannins, saponins, and alkaloids. Antioxidant activity was determined by using DPPH, phosphomolybdate, and reducing power assays. Proximate and elemental analysis was performed by using standard methods. Brine shrimp larvae assay was used to determine the cytotoxicity of chloroform and methanol extract. Chloroform and methanol extract of the plant indicated the presence of $1.56 \times 10^{-4} \mathrm{mg} \mathrm{g}^{-1}$ and $1.28 \times 10^{-4} \mathrm{mg} \mathrm{g}^{-1}$ phenolic, respectively. The plant was found to have high carbohydrate and protein contents. The high-level mineral composition was determined containing Potassium, Sodium, Iron, Zinc, and Copper. Results of antioxidant activity by the DPPH method indicated $\mathrm{IC}_{50}$ of $235.37 \mu \mathrm{g} \mathrm{ml}^{-1}$ and $552.01 \mu \mathrm{g}$ $\mathrm{ml}^{-1}$ for chloroform and methanol extract, respectively. Brine shrimp larvae assay was used to determine the cytotoxicity resulting $\mathrm{LD}_{50}$ of $246.4469 \mu \mathrm{g} \mathrm{ml}^{-1}$ and $169.85 \mu \mathrm{g} \mathrm{ml}^{-1}$ of methanol and chloroform extract, respectively. The study inferred that $C$. bursa-pastoris could serve as a good source of protein and energy as well as micronutrients in the form of a leafy vegetable for human consumption.
\end{abstract}

Keywords: Antioxidant activity; Capsella bursa-pastoris; phytochemical analysis; potohar region of Pakistan; wild vegetable.

\section{Introduction}

Plants are rich sources of phytochemicals and nutraceuticals that gain more attention due to their antioxidant and biological activities (Tsao \& Akhtar, 2005). Disease-preventing food and ingredients called nutraceuticals have been studied extensively from the last decade. The key nutraceutical formulations are known to contain bioactive peptides, oligosaccharides, phenolic compounds, and other products (Hashmi et al., 2010).

Wild plants are important sources of micronutrients and secondary metabolites. The role of these diverse species in sustaining human and environmental health has been highlighted, predominantly about sustainable development and global food security (Frison et al., 2006; Johns \& Eyzaguirre, 2006). Many studies have been reported on wild plants to explore their extraordinary therapeutic and nutritional values (Pardo-de-Santayana et al., 2007). Edible plants rich in secondary metabolites and having antioxidant activities are considered important functional foods (Podsedek et al., 2007).

In recent years, the interest in natural antioxidants, especially of plant origin, has greatly increased (Jayaprakasha \& Jaganmohan, 2000). Antioxidants protect cell damage in human by reducing the adverse effects of free radicals and reactive oxygen species. Free radicals are involved 
in the initiation of oxidation, leading to various diseases like cancer, neural disorder, cardiovascular diseases, aging, and atherosclerosis (Racko et al., 2007). Many synthetic antioxidant agents are available in the market, but they are toxic to animals and human beings. Therefore, the interest of investigators to search for antioxidant agents has been increased (Vinay et al., 2010).

Capsella bursa-pastoris a member of family Brassicaceae, commonly known as shepherd/s purse. It is a wild plant with several medicinal properties such as wound-healing anti-bleeding, antithrombin, antimicrobial, antioxidant, antibacterial, and anticancer effects (Soleimanpour et al., 2013). Ethnomedicinally, C. bursa-pastoris is used to treat various human ailments such as stimulant, astringent, anti-diarrheal, and diuretic (Ajmal et al., 2012). Seeds of the plant are useful in dropsy, diarrhea, and wound healing (Jan et al., 2010). Besides medicinal properties, C. bursa-pastoris also has nutritional properties and is eaten as raw or cooked (Grosso et al., 2011). Although the plant has been used to eat, no report on the nutritional, mineral, cytotoxic, and antioxidant profile of C. bursa-pastoris (L.) indigenous to Pakistan has been presented so far. Therefore, the current study was conducted to evaluate the antioxidant, cytotoxic, and nutritional potential of $C$. bursa-pastoris (L.) from Pakistan.

\section{Materials and methods}

\subsection{Preparation of plant extract}

The whole plant of C. bursa-pastoris (L.) was collected from the Potohar region, Pakistan. Collected plant material was shade dried, pulverized, and stored in air-tight bags for further use.

Extraction was carried out by using the cold maceration technique (Duraipandiyan et al., 2006). $20 \mathrm{~g}$ of powdered plant material was dipped in $200 \mathrm{ml}$ methanol and chloroform separately for seven days, after which the crude extracts were filtered. The residues were dipped in solvents again for a further seven days. The filtrates were combined, and the extra solvent was evaporated using a rotary evaporator.

\subsection{Preliminary phytochemical analysis}

Preliminary phytochemical screening of plant powder was performed using standard protocol to determine the presence or absence of various phytochemicals like alkaloids, terpenoids, phenolics, steroids, saponins, and tannins, etc. (Batool et al., 2019).

\subsection{Determination of alkaloids}

Powdered plant material (50 mg) was taken and mixed with acetic acid (10\%), covered with aluminum foil, and left at room temperature $\left(26^{\circ} \mathrm{C}\right)$ for 4 hours. After filtration, the filtrate was heated on a water bath to reduce its original volume to one-fourth. Few drops of concentrated ammonium hydroxide were added to the solution, and precipitates formation was observed. A filter paper soaked in diluted ammonium hydroxide was used to filter the mixture. The dried filter paper having precipitates were weighed to determine the quantity of alkaloids.

\subsection{Determination of tannins}

Powdered plant material (50 mg) was mixed with $100 \mathrm{ml}$ of distilled water and kept in a shaker for 1 hour, and filtered. Plant filtrate $(5 \mathrm{ml})$ was mixed with $2 \mathrm{ml}$ of ferric chloride $(0.1 \mathrm{mM})$ and potassium ferrocyanide $(0.008$ M) and incubated for $10 \mathrm{~min}$. Absorbance was taken at $495 \mathrm{~nm}$ to determine the quantity of tannins.

\subsection{Determination of saponins}

Plant extract $(50 \mathrm{mg})$ was mixed with 100 $\mathrm{ml}$ of $20 \%$ ethanol and incubated on a water bath at $55^{\circ} \mathrm{C}$ for 4 hours. The heated mixture was filtered, and the filtrate was mixed again in $20 \%$ ethanol and heated for 4 hours on a water bath. The filtrate was shifted to a 
separating funnel, and $20 \mathrm{ml}$ of diethyl ether was added to it, followed by vigorous agitation. After the formation of the aqueous layer, $60 \mathrm{ml}$ of $\mathrm{n}$-butanol was added to it. The solution was washed by using $10 \mathrm{ml}$ of $5 \%$ of sodium chloride. The mixture was dried to get solid residue which was weighed to determine the quantity of saponins.

\subsection{Determination of flavonoids}

To analyze flavonoids, $10 \mathrm{ml}$ methanol (80\%) was mixed with $50 \mathrm{mg}$ of plant material and filtered. The filtrate was left till dryness. Its weight indicated the quantity of flavonoids.

\subsection{Determination of total phenolics}

Gallic acid was used as a standard for which different concentrations were made. Powdered plant material (5 g) of C. bursapastoris was mixed in ethanol and shaken for 2 hours on a mechanical shaker. $9 \mathrm{ml}$ distilled water was added in $1 \mathrm{ml}$ folin ciocalteau reagent. $25 \mu \mathrm{l}$ of reagent mixture and $1 \mathrm{ml}$ of $\mathrm{Na}_{2} \mathrm{CO}_{3}(20 \%)$ were poured into the beaker with a plant sample. Absorbance was recorded after 5-10 min at $765 \mathrm{~nm}$.

\subsection{Proximate analysis}

Moisture, crude fat, crude protein, fiber, Carbohydrate, and ash analysis were made by following the Association of Official Analytical Chemist (AOAC) techniques.

\subsection{Mineral analysis}

Different minerals in plant samples were determined through the wet digestion method. Eight elements were analyzed, in which six were micro-nutrients ( $\mathrm{Zn}$, $\mathrm{Fe}, \mathrm{Mn}, \mathrm{Cu}, \mathrm{Cr}$, and $\mathrm{Cd}$ ) while two were macro-nutrients $(\mathrm{Na}, \mathrm{K})$. Atomic absorption spectrophotometer was used to analyze the concentration of $\mathrm{Cr}, \mathrm{Zn}, \mathrm{Fe}, \mathrm{Mn}, \mathrm{Cu}$, and $\mathrm{Cd}$ in the samples, and flame photometry was used to know the concentration of $\mathrm{Na}$ and $\mathrm{K}$ (Ahmed et al., 2019).

\subsection{Antioxidant Assays}

Sample was dissolved in $95 \%$ methanol to make a concentration of $1 \mathrm{mg} \mathrm{ml}^{-1}$ and diluted to prepare serial dilutions for antioxidant assays (Chaves et al., 2020)

\subsection{DPPH radical scavenging assay}

DPPH assay was carried out by mixing $2 \mathrm{ml}$ of DPPH solution with $100 \mu 1$ of the plant samples at concentrations $25-250 \mu \mathrm{g} \mathrm{ml}^{-1}$. This solution was incubated in the dark for 15-20 minutes. Absorbance of solution was measured at $517 \mathrm{~nm}$, and scavenging activity was anticipated using the formula:

Scavenging effect $(\%)=[\mathrm{AC}-\mathrm{AS} / \mathrm{AC}] \times$ 100

AC: Absorbance (Control)

AS: Absorbance (Sample)

\subsection{Phosphomolybdate assay}

Different concentrations $\left(25-250 \mu \mathrm{g} \mathrm{ml}^{-1}\right)$ of plant extracts were made, and $0.1 \mathrm{ml}$ of these extracts were mixed with $1 \mathrm{ml}$ of a reagent made by mixing $0.6 \mathrm{M}$ Sulphuric acid, $4 \mathrm{mM}$ ammonium molybdate, and $28 \mathrm{mM}$ sodium phosphate. The mixture was incubated in a water bath for 90 minutes at $95^{\circ} \mathrm{C}$ then cooled at room temperature. The absorbance of the mixture was measured at $765 \mathrm{~nm}$. Ascorbic acid was taken as standard. The antioxidant capacity was calculated by using the formula:

Scavenging effect $(\%)=[\mathrm{AC}-\mathrm{AS} / \mathrm{AC}] \times$ 100

AC: Absorbance (Control)

AS: Absorbance (Sample)

\subsection{Reducing power assay}

Various concentrations of extracts were mixed with $2.5 \mathrm{ml}$ of phosphate buffer and $2.5 \mathrm{ml}$ of potassium ferricyanide; this mixture was incubated for 20 minutes at $37^{\circ} \mathrm{C}$. Trichloro acetic acid (10\%) was added 
to the cool mixture followed by the addition of $2 \mu \mathrm{l}$ ferric chloride and left for 10 minutes. Absorbance was measured at $700 \mathrm{~nm}$. The exact concentration of ascorbic acid was used as standard.

\subsection{Cytotoxicity assay}

Brine shrimp lethality assay was used to find out in vivo cytotoxicity (Waghulde et al., 2019). The hatching tank was filled with artificial seawater, prepared by mixing $38 \mathrm{~g} \mathrm{~L}^{-1}$ salt with distilled water and solution having $\mathrm{pH}$ 7.4. Shrimp eggs were transferred into the tank and incubated for 48 hours at $25^{\circ} \mathrm{C}$ under the light.

$21 \mathrm{mg}$ of crude extract was dissolved in 350 $\mu \mathrm{l}$ of DMSO (stock). Different concentrations (50-500 $\mu \mathrm{g} \mathrm{ml}^{-1}$ ) of crude extract were prepared, and when the solvent was evaporated, 15 shrimp nauplii were added to each test tube. The final volume of $5 \mathrm{ml}$ was made by using artificial seawater. The test tubes were incubated at 25$27^{\circ} \mathrm{C}$ for 24 hours, and then the survived nauplii were counted. One test-tube with cytotoxic drug (potassium dichromate) and the other with DMSO was used as a positive and negative control. Death percentage was calculated by using formula:

Death $(\%)=(\mathrm{pc}-\mathrm{pt} / \mathrm{pc}) \times 100$

Where Pt showed dead shrimps and Pc showed control. LC $_{50}$ was calculated at a $95 \%$ confidence interval, respectively.

\subsection{Statistical analysis}

All experiments were performed in triplicates and were expressed as mean, standard deviation. Analysis of data was done by applying analysis of variance (ANOVA) in Statistics 10.1.

\section{Results and discussions}

\subsection{Phytochemical analysis}

Phytochemical analysis of extracts was done to determine the presence or absence of tannins, saponins, terpenoids, phenolics, flavonoids, cardiac glycosides, alkaloids, steroids, and
Phelobetinin (Table 1). Results confirmed the presence of flavonoids, tannins, saponins, cardiac glycosides, alkaloids, and steroids. Chloroform and methanol extracts were rich in phenolic content, indicating the presence of $1.56 \times 10^{-4} \mathrm{mg} \mathrm{g}^{-1}$ and $1.28 \times 10^{-4} \mathrm{mg} \mathrm{g}^{-1}$ $\mu \mathrm{g} \mathrm{mg}^{-1}$, respectively. The total phenolics content in the plant extracts was expressed as $\mathrm{mg}$ of gallic acid equivalent ( $\mathrm{mg} \mathrm{GAE} \mathrm{g}^{-1}$ extract). Alkaloids were found in the range of $0.58 \mathrm{mg} \mathrm{g}^{-1}$. The quantity of flavonoids, saponins, and tannins in C. bursa-pastoris were $0.4 \mathrm{mg} \mathrm{g}^{-1}, 0.26 \mathrm{mg} \mathrm{g}^{-1}$, and $0.46 \mathrm{mg}$ $\mathrm{g}^{-1}$, respectively.

High concentrations of phenolic contents indicate the medicinal importance of plants as they reduce the chances of cancer obesity, urinary infections, cardiovascular and periodontal diseases (Huang \& Kun, 2011). Alkaloids are analgesic and antiinflammatory, which aid in relieving pain and boost immune response. Plants with a substantial quantity of alkaloids are known for treating asthma, skin diseases, and snake bites (Mazid et al., 2011). Flavonoids have a strong ability to adjust the response of the body to viruses, carcinogens, and allergies (Ullah \& Khan, 2008). Epidemiological studies revealed that intake of flavonoids and vegetables and fruits could lower cancer cases in humans. They can cause inactivation of carcinogens, cell cycle arrest, scavenging of reactive species, and initiation of apoptosis (Vasantha et al., 2012).

The presence of saponins in plant extract is a good indication regarding its medicinal importance as saponins poses hypocholesterolemic, anti-inflammatory, antimicrobial, antidiabetic, anticancer, antioxidant, molluscidal, anticonvulsant, antispasmodic, analgesic, anthelmintic, and cytotoxic effects (Yuan et al., 2011). Tannins also possess defensive properties and antitumor effects. They can accelerate blood clotting, decrease the lipids in serum, reduce blood pressure and modulate immunologic responses (Ali et al., 2011). The presence of these phytochemicals indicates the medicinal importance of this plant species. 
Table 1. Qualitative and quantitative phytochemical analysis of C. bursa-pastoris.

\begin{tabular}{||ccc||}
\hline \hline Phytochemicals & Quantity & Present/Absent \\
Alkaloids & $0.58 \mathrm{mg} \mathrm{g}^{-1}$ & Present \\
Flavonoids & $0.4 \mathrm{mg} \mathrm{g}^{-1}$ & Present \\
Tannins & $0.46 \mathrm{mg} \mathrm{g}^{-1}$ & Present \\
Saponins & $0.26 \mathrm{mg} \mathrm{g}^{-1}$ & Present \\
Phenolics & $1.56 \times 10^{-4} \mathrm{mg} \mathrm{g}^{-1} \mathrm{GAE}$ & Present \\
Terpenoids & - & Absent \\
Anthraquinones & - & Absent \\
Coumarins & - & Absent \\
Cardiac glycosides & - & Present \\
Phelobetinin & - & Absent \\
Steroids & - & Present \\
Resin & - & Present \\
\hline
\end{tabular}

\subsection{Proximate analysis}

Vegetables play a significant role in raising the health status of the common man in developing countries. They are a cost-effective and rich source of minerals, vitamins, and fibers. They are also consumed in little quantity as a side dish with staple foods (Hala et al., 2011). Proximate analysis of the C. bursa-pastoris indicated the presence of carbohydrate $(52.5 \%)$, crude protein $(21.8 \%)$, crude fiber $(4.5 \%)$, and ash $(12.2 \%)$. The presence of significant quantities of nutritious compounds indicated the importance of C. bursa-pastoris (L.) as a source of nutrition (Figure. 1). These results indicate that the use of C. bursa-pastoris (L.) as a vegetable will pose good impacts on health, contrary to previously studied wild vegetables like Aegle marmelos, whose crude protein crude fat, and crude fiber were much less than this plant (Iyaka, 2007).

\subsection{Mineral analysis}

Edible vegetables contain an appreciable amount of inorganic minerals, which are highly beneficial for human health and disease prevention (Singh et al., 2012; Fasuyi, 2006). Elemental analysis of $C$. bursa showed the presence of different minerals in different amounts, potassium has highest amount (67.5 ppm) followed by sodium (21 ppm) (Table 2). While in micronutrients Fe, $\mathrm{Zn}, \mathrm{Mn}$, and Cuwere present in a concentration of $0.195 \mathrm{ppm}, 0.455$ ppm, 0.297 ppm, and 1.245 ppm, respectively. Sodium is important in the regulation of blood pressure and volume (Rodriguez et al., 2006). Iron is an important micronutrient that is necessary for the transportation of oxygen in the body. Iron also serves as a cofactor for several enzyme activities. Zinc is important in many processes, such as regulating cellular growths, gene expression, and acting as a cofactor for enzyme activities (Idris et al., 2010). Manganese is involved in skeletal growth and development and, with vitamin $\mathrm{K}$, function in the formation of prothrombin. It also acts as an important cofactor for many enzyme activities (Camera \& Amaro, 2003). Copper plays an important role in the regulation of the function of red blood cells. However, its high concentration can lead to many disorders such as vomiting, blood in the urine, diarrhea, epigastric pain and discomfort, liver damage, and hypotension (McDonald, 1995). These important minerals indicate the nutritional importance of plants and recommend their use as an important functional food.

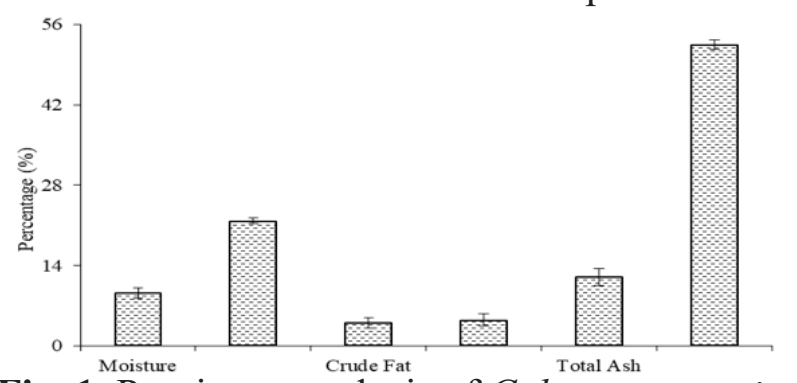

Fig. 1. Proximate analysis of C. bursa-pastoris. 
Table 2. Mineral composition of C. bursa-pastoris.

\begin{tabular}{|cc|}
\hline Minerals & Concentration (ppm) \\
$\mathrm{Cd}$ & 0.031 \\
$\mathrm{Fe}$ & 0.195 \\
$\mathrm{Mn}$ & 0.297 \\
$\mathrm{Zn}$ & 0.455 \\
$\mathrm{Cu}$ & 1.245 \\
$\mathrm{Cr}$ & 2.192 \\
$\mathrm{Na}$ & 21 \\
$\mathrm{~K}$ & 67.5 \\
\hline \hline
\end{tabular}

\subsection{Antioxidant Activity}

\subsubsection{DPPH assay}

Both chloroform and methanol extracts showed significant antioxidant potentials, but chloroform extract was more potent to scavenging ability as compared to methanol extract (Figure. 2). The $\mathrm{IC}_{50}$ value was calculated through a linear regression equation. The lowest $\mathrm{IC}_{50}$ value was for ascorbic acid, i.e., 44.49, followed by chloroform, i.e., $235.37 \mu \mathrm{g} \mathrm{ml}^{-1}$ and methanol, i.e., $552.01 \mu \mathrm{g} \mathrm{ml}^{-1}$ in ascending manner. The extracts had significant scavenging effects on the DPPH radical, which was increasing with the increase in the concentration of the sample from $25-250 \mu \mathrm{g} \mathrm{ml}^{-1}$. A similar DPPH free radical scavenging activity trend is already well documented (Thambiraj \& Paulsamy, 2012; Vishnu et al., 2013).
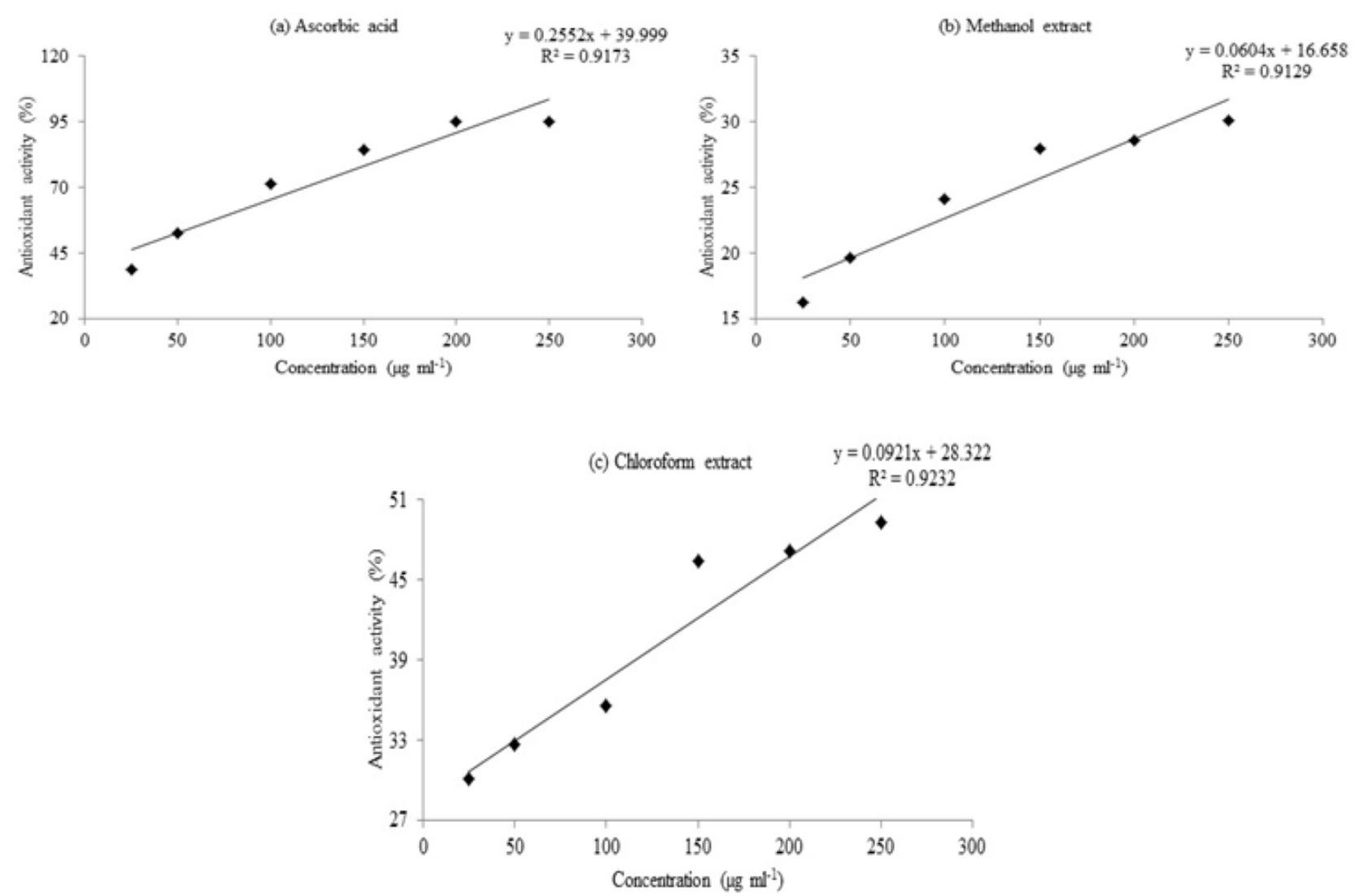

Fig. 2. DPPH free radical scavenging behavior extracts of C. bursa-pastoris and Ascorbic acid (a) Ascorbic acid (b) Methanol extract (c) Chloroform extract. 


\subsubsection{Phosphomolybdate assay}

Phosphomolybdate assay is employed to find out the whole antioxidant activity of extracts (Johnson, 2005). Results of the study indicated that non-polar (chloroform) extract exhibited the highest radical scavenging $37.2 \pm 0.80 \%$ at maximum concentration, followed by polar (methanol) solvent, i.e., $35.6 \pm 0.8 \%$ as compared to standard (Figure. 3). The lowest $\mathrm{IC}_{50}$ value was exhibited by chloroform extract, indicating more antioxidant compounds in this extract.

\subsubsection{Reducing Power Assay}

The reducing power of the extracts may serve

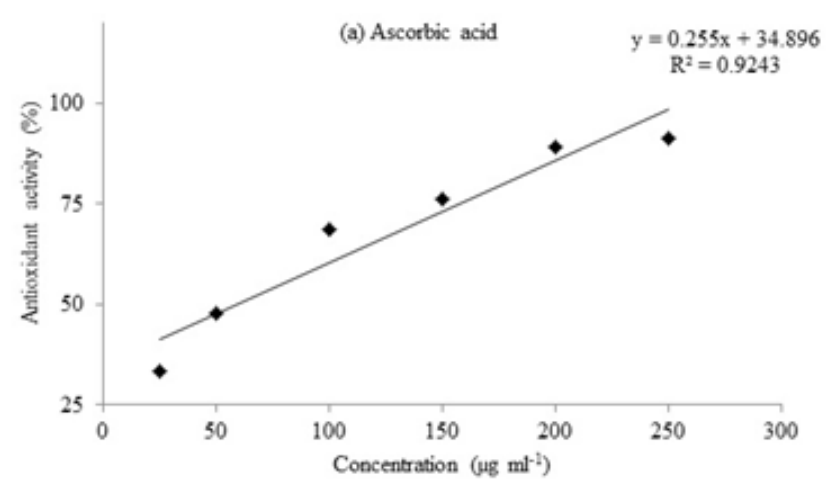

as a significant indicator of its potential antioxidant activity. A dose-dependent response was observed in reducing power assay. The absorbance of the samples was recorded as $0.146 \pm 0.07$ and $0.143 \pm 0.002$ in the case of methanol extract followed by chloroform extract at a concentration of 250 $\mu \mathrm{g} \mathrm{ml}^{-1}$ (Figure. 4). In the case of reducing assay, methanol extract revealed better activity with a minor difference. Antioxidant compounds in the extracts donate electrons to reactive radicals, reducing them into more stable and unreactive species (Gulcin, 2003). The total content of phenolics and flavonoids in extracts positively correlates with their antioxidant properties, indicating their role in the antioxidant activities of the plant.

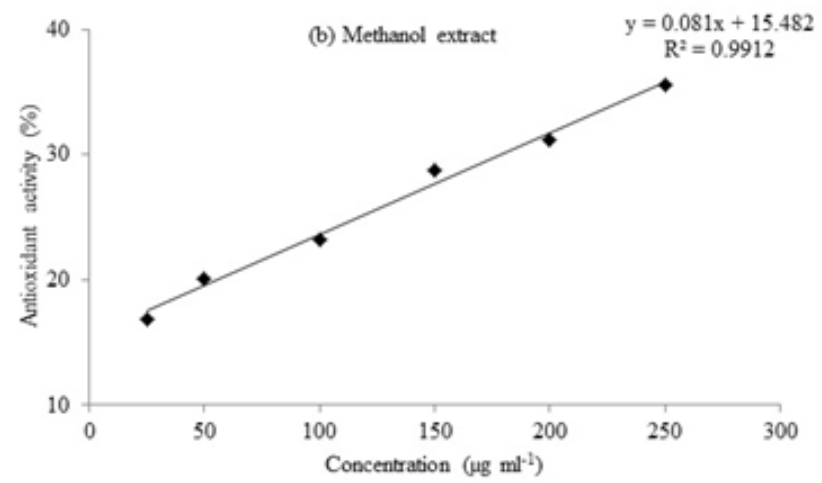

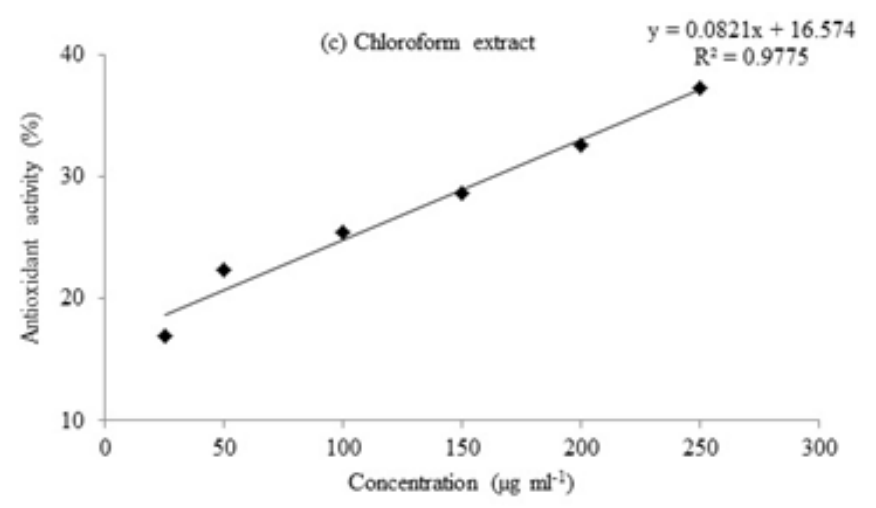

Fig. 3. Phosphomolybdate radical scavenging behavior of extracts and ascorbic acid reducing power assay (a) Ascorbic acid (b) Methanol extract (c) Chloroform extract. 

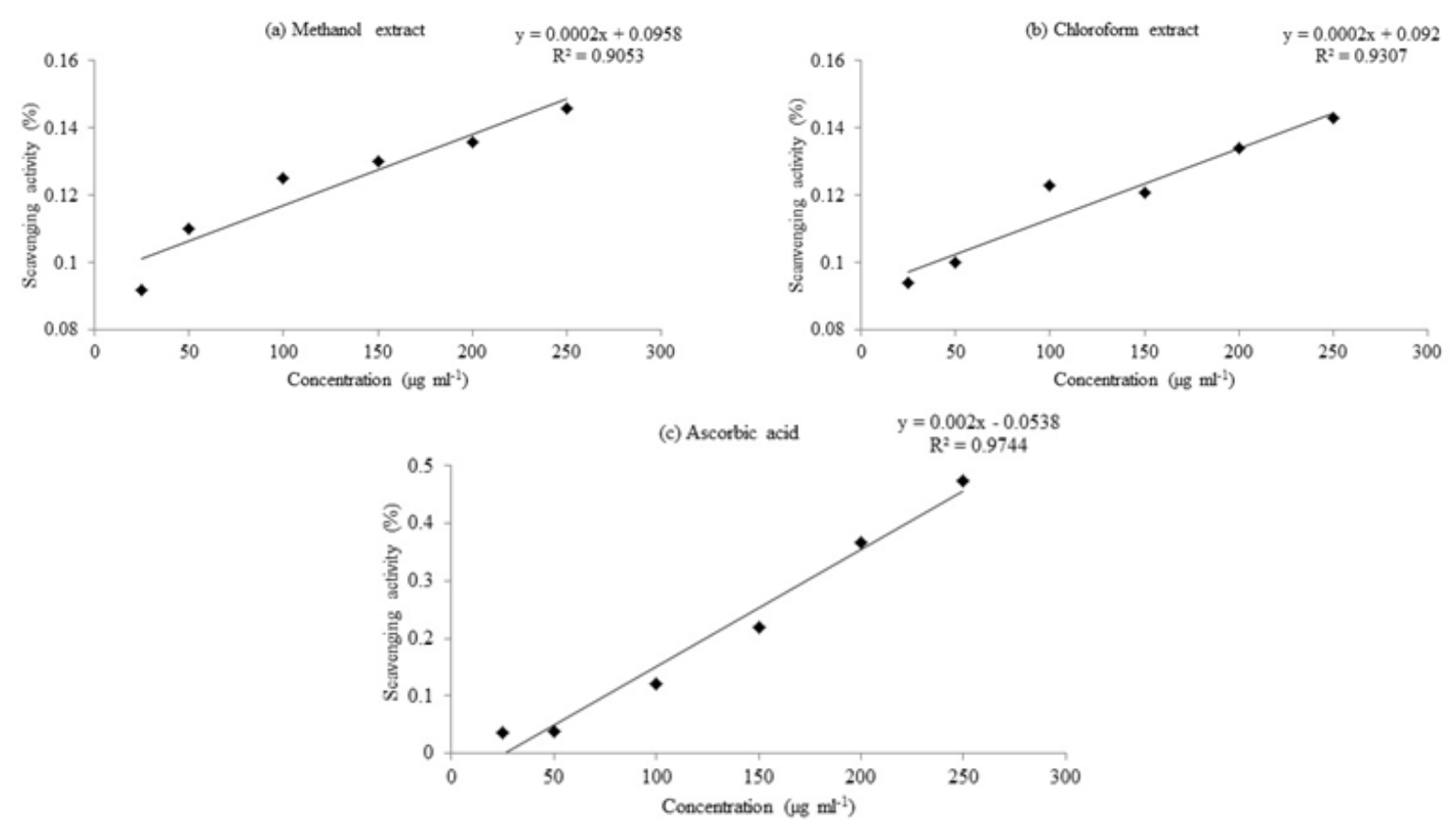

Fig. 4. Radical scavenging activities of extracts of C. bursa-pastoris and Ascorbic acid for reducing power assay (a) Ascorbic acid (b) Methanol extract (c) Chloroform extract.

\subsection{Cytotoxicity of $C$. bursa-pastoris}

Methanol (polar) and Chloroform (nonpolar) extracts of C. bursa-pastoris were assessed against brine shrimp for cytotoxicity analysis. Both methanol and chloroform extracts of the plant showed lethality in a concentration-dependent manner. The methanol extract showed $\mathrm{LD}_{50} 246.4469 \mu \mathrm{g}$ $\mathrm{ml}^{-1}$, whereas the chloroform extract showed $\mathrm{LD}_{50}$ value of $169.85 \mu \mathrm{g} \mathrm{ml}^{-1}$ (Figure. 5). In the present study, the chloroform plant extract showed significant cytotoxic properties as compared to methanol extract. Results of cytotoxic activity indicated the presence of bioactive compounds in the extracts that can be responsible for antitumor and antiinflammatory activities of the plant.

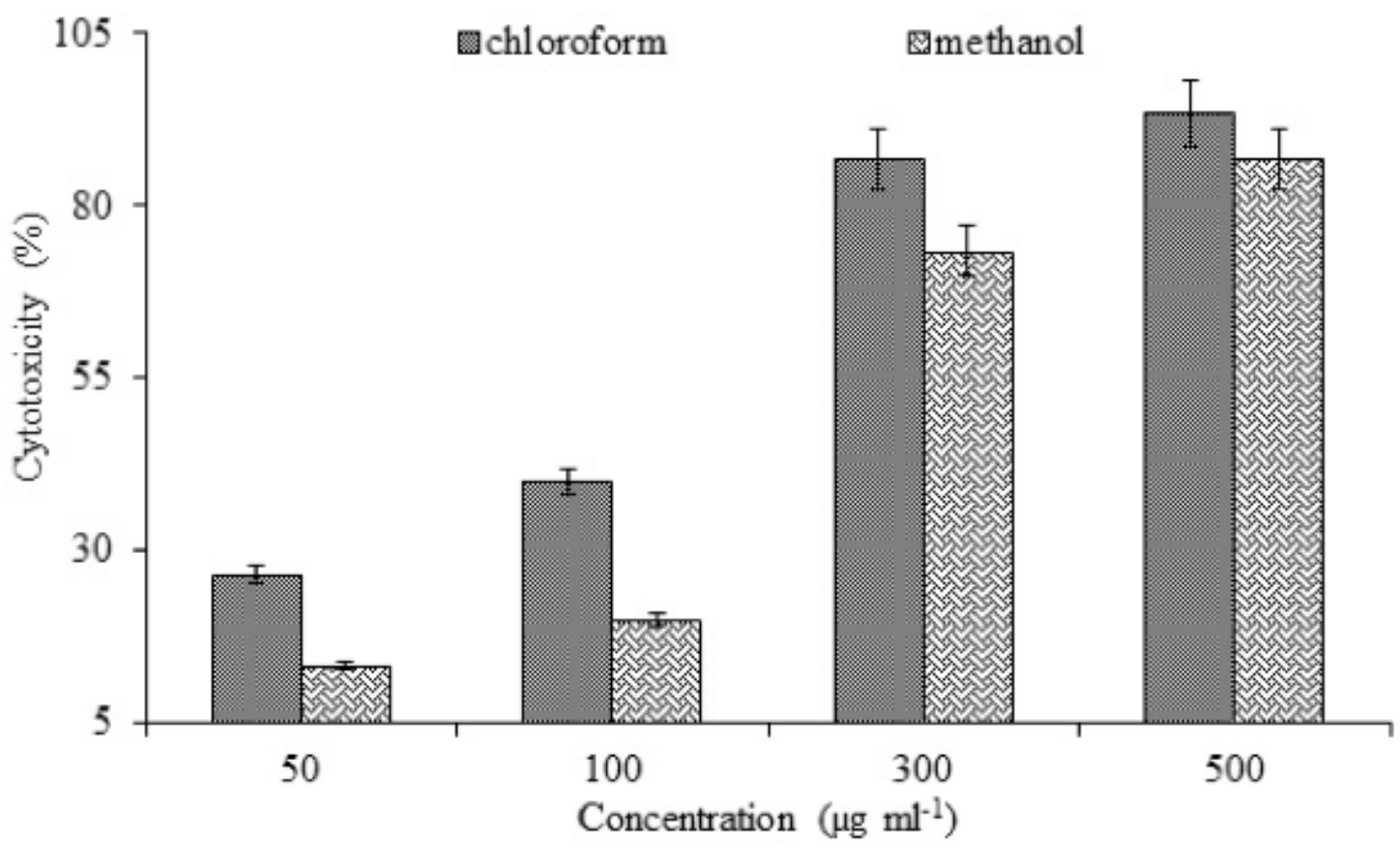

Fig. 5. Brine shrimp lethality at various concentrations of $C$. bursa-pastoris. 


\section{Conclusion}

C. bursa-pastoris is a nutritionally good plant, eaten raw or cooked with crude protein, fiber, fat, carbohydrate, and minerals. Overall the investigated plant is a good source of nutrition and poor in anti-nutritional components. C. bursa-pastoris is also a rich source of antioxidants, which prevent free radical damage and reduce the risk of chronic diseases. Further studies can be carried out to investigate the profile of active compounds present in the extracts responsible for pharmacological properties.

\section{References}

Ahmed, M.; Ji, M.; Sikandar, A.; Iram, A.; Qin, P. et al. (2019) Phytochemical analysis, biochemical and mineral composition and GCMS profiling of methanolic extract of Chinese Arrowhead Sagittaria trifolia L. from Northeast China. Molecules, 24(17):3025.

Ajmal, S.M.; Mohammad, S.; Zahid, K.; Bakht, Z.; Habib, A. et al. (2012) Ethnomedicinal and pyhtoeconomic elaboration of Lilownai valley, District Shangla, Pakistan. International Research Journal of Pharmacy, 3(4):164-169.

Ali, N.; Syed, A.S.; Shah, I.W.; Mehreen, A.G.G. \& Khan, I. (2011) Cytotoxic and anthelmintic potential of crude saponins isolated from Achillea wilhelmsii $C$. Koch and Teucrium stocksianum boiss. BMC Complementary and Alternative Medicine, 11:106.

Batool, R.; Khan, M.R.; Sajid, M.; Ali, S. \& Zahra, Z. (2019) Estimation of phytochemical constituents and in vitro antioxidant potencies of Brachychiton populneus (Schott \& Endl.) R.Br. BMC Chemistry, 13(32):1-15.

Camera, F. \& Amaro, C.A. (2003) Nutritional aspect of zinc availability. International Journal of Food Sciences and Nutrition, B:143-151.
Chaves, N.; Santiago, A. \& Alías, J.C. (2020) Quantification of the antioxidant activity of plant extracts: Analysis of sensitivity and hierarchization based on the method used. Antioxidants, 9(1):76.

Duraipandiyan, V.; Ayyanar, M. \& Ignacimuthu, S. (2006) Antimicrobial activity of some ethnomedicinal plants used by Paliyar tribe from Tamil Nadu, India. BMC Complementary and Alternative Medicine, 35 (6):1-7.

Fasuyi, A.O. (2006) Nutritional potentials of some tropical vegetable meals. Chemical characterization and functional properties. African Journal of Biotechnology, 5:49-53.

Frison, E.A.; Smith, I.F.; Johns, T.; Cherfas, J. \& Eyzaguirre, P. (2006) Agricultural biodiversity, nutrition, and health: making a difference to hunger and nutrition in the developing world. Food and Nutrition Bulletin, 27:167-179.

Grosso, C.; Vinholes, J.; Silva, L.R.; Pinho, P.G.; Gonçalves, R.F. et al. (2011) Chemical composition and biological screening of Capsella bursa-pastoris. Brazilian Journal of Pharmacognosy, 21(4):635-644.

Gulcin, I.; Oktay, M.; Kirecci, E. \& Kufrevioglu, O. I. (2003) Screening of antioxidant and antimicrobial activities of anise (Pimpinella anisum L.) seed extracts. Food Chemistry, 83:371-382.

Hala, U.; Gali-Muhtasib, I.H.; Younes, J.J.; Karchesy \& Marwan, E.E. (2011) Plant tannins inhibit theinduction ofaberrantcryptfoci and colonic tumors by 1, 2-dimethylhydrazine in mice. Nutrition and Cancer, 39(1):108-116.

Hashmi, S.I.; Satwadhar, P.N.; Khotpal, R.R.; Deshpande, H.W.; Syed K.A. et al. (2010) Rapeseed meal nutraceuticals. Journal of Oilseed Brassica, 1(2):43-54. 
Huang, D.; Ou, B. \& Prior, R.L. (2005) The chemistry behind antioxidant capacity assays. Journal of Agriculture and Food Chemistry, 53(6):1841-1856.

Idris, S.; Ndamitso, M.M.; Yisa, J.; Dauda, B.E.N., \& Jacob, J.O. (2010) The proximate and mineral composition of the leaves and stems of Balanites aegyptiaca. International Journal of Advanced Biological Research, 2(1):76-87.

Iyaka Y.A. (2007) Concentration of $\mathrm{Cu}$ and Zinc in some fruits and vegetables commonly available in North-Central zone of Nigeria. Electronic Journal of Environmental, Agricultural and Food Chemistry, 6(6):21502154.

Jan, G.; Khan, M.A.; Gul, F.; Ahmad, M.; Jan M. et al. (2010) Ethnobotanical study of common weeds of Dir Kohistan valley, Khyber Pakhtoonkhwa, Pakistan. Pakistan Journal of Weed Science Research, 16(1):81-88.

Jayaprakasha, G.K. \& Jaganmohan, R. (2000) Phenolic constituents from lichen Parmontrema stuppeum. Hale and antioxidant activity. Journal for Nature Research, C55:1018-22

Johns, T.E., \& Eyzaguirre, P.B. (2006) Linking biodiversity, diet, and health in policy and practice. Proceedings of the Nutrition Society, 65:182-189.

Johnson, W.T. (2005) Copper and brain function. In: Lieberman, H.R. Kanarek, R.B. \& Prasad, C. (Ed.). Nutritional and Neuroscience. Pp. 289-305. CRC Press, Boca Raton.

Mazid, M.; Khan, T.A. \& Mohammad, F. (2011) Role of secondary metabolites in defense mechanisms of plants. Experimental Biology and Medicine, 3(2):232-249.

McDonald, P.; Edward, R.A.; Greenhalti, F.D., \& Morgan, C.A. (1995) Animal nutrition. Prentices Hall, London. Pp 101-122.
Pardo de Santayana, M.; Tardı'o, J.; Blanco, E.; Carvalho, A.M.; Lastra, J.J. et al. (2007) Traditional knowledge of wild edible plants used in the northwest of the Iberian Peninsula (Spain and Portugal): A comparative study. Journal of Ethnobiology and Ethnomedicine, 3:16-27.

Podsedek, A. (2007) Natural antioxidants and antioxidant capacity of Brassica vegetables: A review. LWT-Food Science and Technology, 40:1-11.

Racko, L.; Oblozinsky, M.; Kostalova, D.; Kettmann, V. \& Bezakova, L. (2007) Free radical scavenging activity and lipoxygenase inhibition of Mahonia aquifolium extract and isoquinoline alkaloids. Journal of Inflammation, 4:15-21.

Rodriguez, R.; Jimenez, A.; FernandezBolanos, J.; Guillen, R. \& Heredia, A. (2006) Dietary fiber from vegetable products as source of functional ingredients. Trends in Food Science Technology, 17:3-15.

Singh, U.; Kochhar, A. \& Boora, R. (2012) Proximatecomposition, available carbohydrates, dietary fibers, and anti-nutritional factors in BAEL (Aegle maemelos L.) leaf, pulp, and seed powder. International Journal of Scientific and Research Publications, 2(4):1-4.

Soleimanpour, S.; Sedighinia, F.S.; Afshar, A.S.; Zarif, R.; Asili, J. et al. (2013) Synergistic antibacterial activity of Capsella bursa-pastoris and Glycyrrhiza glabra against oral pathogens. Jundishapur Journal of Microbiology, 6(8):1-6.

Thambiraj, J. \& Paulsamy, S. (2012) In vitro antioxidant potential of methanol extract of the medicinal plant, Acacia caesia (L.) Willd. Asian Pacific Journal of Tropical Biomedicine, 2:S732-S736.

Tsao, R. \& Akhtar, M.H. (2005) Nutraceuticals and functional foods. Current trend in phytochemical antioxidant research. Journal of Food Agriculture and Environment, 3(1):10-7. 
Ullah, M.F. \& Khan, M.W. (2008) Food as medicine: Potential therapeutic tendencies of plant-derived polyphenolic compounds. Asian Pacific Journal of Cancer Prevention, 9:187195.

Vasantha, K.; Priyavardhini, S.; Soris, P. T. \& Mohan, V.R. (2012) Phytochemical analysis and antibacterial activity of Kedrostis foetidissima (Jacq.) Cogn. Bioscience Discovery, 3(1):06-16.

Vinay, R.P.; Prakash, R.P. \& Sushil, S.K. (2010) Antioxidant activity of some selected medicinal plants in western region of India. Journal of Advanced Biomedical Research, 4:23-26

Vishnu, R.; Nisha, R.; Jamuna, S. \& Paulsamy, S. (2013) Quantification of total phenolics and flavonoids and evaluation of in vitro antioxidant properties of methanolic leaf extract of Tarenna asiatica - an endemic medicinal plant species of Maruthamali hills, Western Ghats, Tami Nadu. Journal of Plant Research, 2:196-204.

Waghulde, S.; Kale M.K. \& Patil, V.R. (2019) Brine Shrimp Lethality assay of the aqueous and methanolic extracts of the selected species of medicinal plants. Proceedings, 41:47-49.

Yuan, W.; Zhou, L.; Deng, G.; Wang, P.; Creech, D. et al. (2011) Anthocyanins, Phenolics, and Antioxidant Capacity of Vaccinium L. in Texas, USA. Pharmaceutical Crops, 2: 11-23.

$\begin{array}{lr}\text { Submitted: } & 17 / 04 / 2020 \\ \text { Revised: } & 13 / 08 / 2020 \\ \text { Accepted: } & 13 / 09 / 2020 \\ \text { DOI: } & 10.48129 / \text { kjs.v48i3.9562 }\end{array}$

